\title{
Allexiviruses - pathogens of garlic plants
}

\section{Allexiwirusy - patogeny czosnku pospolitego}

\author{
Maria Bereda*, Elżbieta Paduch-Cichal
}

\section{Summary}

Garlic (Allium sativum L.) is one of the most important culinary herbs in Poland. Viral diseases are among the most serious threats to garlic cultivation. As garlic is vegetatively propagated, virus infections are transmitted from one crop cycle to another through infected cloves. The most commons viruses infecting garlic plants are members of three families: Potyviridae (genus Potyvirus), Betaflexiviridae (genus Carlavirus) and Alphaflexiviridae (genus Allexivirus). These viruses have similar morphological properties and often similar biology, thus it is very difficult to distinguish them. Eight virus species belong to the genus Allexivirus: Garlic mite-borne filamentous virus (GarMbFV), Garlic virus A (GarV-A), Garlic virus B (GarV-B), Garlic virus C (GarV-C), Garlic virus D (GarV-D), Garlic virus $E(G a r V-E)$, Garlic virus $X($ GarV-X) and Shallot virus $X$ (ShVX). Infections of allexiviruses can cause severe losses in garlic production fields such as - decrease in bulbs' weight (14-32\%) and reduction of their diameter (6-11\%). Phylogenetic analysis based on nucleotide, as well as amino acid sequences of different genome fragments, has revealed genetic diversity within populations of allexiviruses. Furthermore, the diagnostic methods used for detection of viruses that belong to the genus Allexivirus occurring in garlic plants are described.

Key words: garlic; allexiviruses; genom; genetic diversity; diagnostic methods

\section{Streszczenie}

Czosnek pospolity (Allium sativum L.) jest jedną z najważniejszych roślin przyprawowych uprawianych w Polsce. Ze względu na to, że jest to roślina rozmnażana jedynie w sposób wegetatywny, wirusy przenoszone są z jednego cyklu uprawy na kolejny wraz z zainfekowanymi cebulami. Czosnek jest porażany przede wszystkim przez wirusy należące do trzech rodzin: Potyviridae (rodzaj Potyvirus), Betaflexiviridae (rodzaj Carlavirus) i Alphaflexiviridae (rodzaj Allexivirus). Są to wirusy o zbliżonej morfologii oraz właściwościach biologicznych, dlatego istnieją trudności w rozdzieleniu kompleksu tych wirusów. Do rodzaju Allexivirus należy osiem gatunków wirusów: przenoszony przez szpeciele nitkowaty wirus czosnku (Garlic mite-borne filamentous virus, GarMbFV), wirus $A$ czosnku (Garlic virus A, GarV-A), wirus B czosnku (Garlic virus B, GarV-B), wirus C czosnku (Garlic virus C, GarV-C), wirus D czosnku (Garlic virus D, GarV-D), wirus E czosnku (Garlic virus E, GarV-E), wirus X czosnku (Garlic virus X, GarV-X) i wirus X szalotki (Shallot virus $X, S h V X)$. Obecność allexiwirusów w roślinach czosnku jest przyczyną spadku plonu - redukcja ciężaru cebul (14-32\%) oraz ich średnicy (6-11\%). Na podstawie wyników przeprowadzonych analiz filogenetycznych, opartych na budowie sekwencji nukleotydów i aminokwasów różnych fragmentów genomu poszczególnych gatunków ustalono, że allexiwirusy są zróżnicowane genetycznie. Ponadto przedstawiono metody diagnostyczne wykorzystywane do wykrywania i identyfikacji allexiwirusów w roślinach czosnku pospolitego.

Słowa kluczowe: czosnek; allexiwirusy; genom; zróżnicowanie genetyczne; diagnostyka

\footnotetext{
Szkoła Główna Gospodarstwa Wiejskiego w Warszawie

Samodzielny Zakład Fitopatologii

Nowoursynowska 159, 02-776 Warszawa

*corresponding author: maria_bereda@sggw.pl
} 


\section{Wstęp / Introduction}

Czosnek pospolity (Allium sativum L.) należy do rodziny czosnkowatych (Alliaceae), rzędu amarylkowców (Amaryllidales). Pochodzi z okolicy gór Tien-szan położonych w Azji centralnej. Jest jedną z najstarszych, znanych od około 7 tysięcy lat roślin uprawnych, a ze względu na swoje właściwości nie tylko cenioną i bardzo popularną przyprawą, ale również uznaną rośliną wykorzystywaną w celach leczniczych.

Uprawy czosnku pospolitego zlokalizowane są w różnych rejonach świata, głównie na terenie Chin, Indii i Korei Południowej oraz w krajach basenu Morza Śródziemnego (Hiszpania, Francja, Egipt, Turcja), w Ameryce Południowej (Argentyna, Brazylia), Ameryce Północnej (Meksyk, USA) i Rosji (FAO 2011). W Polsce czosnek pospolity jest uprawiany przede wszystkim na terenie województw: małopolskiego (gminy Radziemice i Słomniki), mazowieckiego (gmina Latowicz), lubuskiego (gmina Chełm) i wielkopolskiego (gminy Dobrzyca i Goleszów).

Obserwowany w ostatnich latach wzrost zainteresowania czosnkiem pospolitym wynika $\mathrm{z}$ jego walorów smakowych i właściwości prozdrowotnych, co wiąże się z koniecznością pozyskiwania wysokiej jakości surowca zarówno dla przemysłu farmaceutycznego, jak i spożywczego. Tymczasem uzyskanie zdrowych, pełnowartościowych cebul nie jest łatwe głównie ze względu na powszechne występowanie chorób wywoływanych przez czynniki infekcyjne, w okresie wegetacji są to grzyby: Fusarium oxysporum, F. avenaceum, Pyrenochaeta terrestris, $P$. verrucosum var. cyclopium, Sclerotium cepivorum, Botrytis sp., a podczas przechowywania bakterie z rodzaju: Bacillus, Erwinia i Pseudomonas.

Szczególne zagrożenie dla czosnku pospolitego stanowią wirusy. Większość uprawianych odmian czosnku pospolitego nie wytwarza nasion, dlatego roślina rozmnażana jest jedynie wegetatywnie przez ząbki i cebulki powietrzne (Etoh 1985; Simon i Jenderek 2003). Powszechnie uważa się, że gatunki roślin rozmnażane wegetatywnie są szczególnie zagrożone przez choroby wirusowe. Przyczyną tego jest nieuchronność przeniesienia wirusa. Z chorej rośliny matecznej zawsze uzyskuje się zawirusowane organy służące do rozmnażania. Drugim czynnikiem jest zjawisko wirusowej degeneracji roślin (Kryczyński 2010). Dodatkowo w trakcie uprawy i przechowywania cebul czosnku pospolitego wirusy mogą być przenoszone przez wektory: owady (mszyce) lub pajęczaki (szpeciele) (King i wsp. 2012). W roślinach czosnku pospolitego wykryto różne gatunki wirusów z rodzajów: Potyvirus, Carlavirus, Cucumovirus, Tobravirus, Tobamovirus, Cytorhabdovirus, Nepovirus, Tospovirus oraz Macluravirus.

Jednym z ważniejszych zagrożeń w uprawie czosnku pospolitego są gatunki wirusów należące do rodzaju Allexivirus ze względu na sposób ich rozprzestrzeniania wraz $\mathrm{z}$ materiałem rozmnożeniowym oraz przenoszenie w okresie wegetacji.

Poznanie biologii i epidemiologii allexiwirusów ma bardzo istotnie znaczenie dla praktyki, zwłaszcza dla służb Państwowej Inspekcji Ochrony Roślin i Nasiennictwa (PIORiN) oraz polskich producentów i w przyszłości pozwoli na podjęcie działań zmierzających do poprawy perspektywy uprawy czosnku pospolitego w Polsce.

Niniejszy artykuł jest przeglądem piśmiennictwa dotyczącego wirusów zaliczonych do rodzaju Allexivirus. Intencją autorów niniejszej pracy było zaprezentowanie zamieszczonych w literaturze przedmiotu zagadnień związanych z występowaniem, szkodliwością, etiologią, epidemiologią, zróżnicowaniem genetycznym allexiwirusów oraz możliwościami wykrywania i identyfikacji tej grupy patogenów w roślinach czosnku pospolitego.

\section{Ogólna charakterystyka wirusów $z$ rodzaju Allexivirus / Characterization of viruses of the genus Allexivirus}

Gatunki należące do rodzaju Allexivirus są nową, mało poznaną grupą wirusów porażających rośliny należące do rodzaju Allium. Pierwsze doniesienia dotyczące przenoszonych przez szpeciele wirusów porażających rośliny cebuli zwyczajnej pochodzą z 1971 roku z terenów obecnej Rosji (Razvjazkina 1971). W 1991 roku Van Dijk opisał dwa gatunki wirusów na terenie Holandii, których wektorem był szpeciel (Aceria tulipae) i nadał im nazwy: przenoszony przez szpeciele utajony wirus cebuli (Onion mite-borne latent virus, OMbLV) oraz przenoszony przez szpeciele utajony wirus szalotki (Shallot mite-borne latent virus, SMbLV). Na podstawie cech morfologicznych i cytopatologicznych autor zaklasyfikował wyizolowane wirusy do rodzaju Rymovirus (rodzina Potyviridae). Późniejsze badania oparte na właściwościach serologicznych wykazały, że uzyskane izolaty są serologicznie podobne do wirusa X szalotki (Shallot virus $X$, ShVX) (Van Dijk i Van der Vlugt 1994). Od tego momentu, kolejnym wykrywanym w roślinach czosnku pospolitego przenoszonym przez szpeciele wirusom nadawano nazwy: wirus A czosnku (Garlic virus A, GarV-A), wirus B czosnku (Garlic virus $B$, GarV-B), wirus C czosnku (Garlic virus $C$, GarV-C) oraz wirus D czosnku (Garlic virus D, GarV-D) (Sumi i wsp. 1993) i na podstawie podobieństwa sekwencji nukleotydów przyporządkowano do jednego rodzaju Allexivirus (Hillman i Lawrence 1995).

Obecnie do rodzaju Allexivirus należą następujące gatunki wirusów (IX Raport ICTV) (King i wsp. 2012): nitkowaty wirus czosnku przenoszony przez szpeciele (Garlic mite-borne filamentous virus, GarMbFV), wirus A czosnku (Garlic virus A, GarV-A), wirus B czosnku (Garlic virus B, GarV-B), wirus C czosnku (Garlic virus $C$, GarV-C), wirus D czosnku (Garlic virus D, GarV-D), wirus E czosnku (Garlic virus E, GarV-E), wirus X czosnku (Garlic virus $X, \mathrm{GarV}-\mathrm{X}$ ) i wirus $\mathrm{X}$ szalotki (Shallot virus $X$, ShVX).

Cząstki wirusów z rodzaju Allexivirus są nitkowate, mocno powyginane o średnicy około $12 \mathrm{~nm}$ i długości około $800 \mathrm{~nm}$ (King i wsp. 2012).

Dotychczas sądzono, że gatunki należące do rodzaju Allexivirus porażają $\mathrm{w}$ naturze jedynie rośliny $\mathrm{z}$ rodzaju Allium (Van Dijk 1991; Van Dijk i Van der Vlugt 1994). Tymczasem Fidan i wsp. (2015) wykryli GarV-D w 41 próbach urgini morskiej (Urginea maritime L., rodzi- 
na Hyacinthaceae) pochodzącej z krajów basenu Morza Śródziemnego.

Allexiwirusy są rozprzestrzeniane $\mathrm{z}$ materiałem rozmnożeniowym, a w okresie wegetacji i podczas przechowywania cebul ich wektorem jest szpeciel Aceria tulipae (Van Dijk 1991).

Gatunki należące do rodzaju Allexivirus notowano w roślinach czosnku pospolitego na terenie Argentyny (Conci i wsp. 1992; Cafrune i wsp. 2006), Australii (Wylie i wsp. 2012b), Brazylii (Melo-Filho i wsp. 2004; Mituti i wsp. 2015), Chin (Chen i wsp. 2001), Czech (Klukáčková i wsp. 2007), Etiopii (Jemal i wsp. 2015), Grecji (Dovas i wsp. 2001), Hiszpanii (Tabanelli i wsp. 2004), Indii (Singh i wsp. 2014), Iranu (Shahraeen i wsp. 2008), Japonii (Sumi i wsp. 1993; Yamashita i wsp. 1996; Sumi i wsp. 1999), Korei (Park i wsp. 2005; Lee i wsp. 2007), Nowej Zelandii (Ward i wsp. 2009), Słowenii (Mavric i Ravnikar 2005), Sudanu (Mohammed i wsp. 2013), Rosji (Kanyuka i wsp. 1992), Stanów Zjednoczonych (Gieck i wsp. 2009), Polski (Chodorska i wsp. 2014) oraz Włoch (Dovas i Volvas 2003). Na rysunku 1. zaprezentowano schemat rozmieszczenia allexiwirusów na świecie.

Szkodliwość gatunków wirusów należących do rodzaju Allexivirus wiąże się z pogorszeniem jakości uzyskiwanego plonu. Badania przeprowadzone na polach uprawnych w Argentynie wykazały, że porażenie przez GarV-A roślin czosnku pospolitego odmiany Blanco i Morado skutkowało obniżeniem ciężaru cebul (14-32\%) oraz redukcją średnicy cebul (6-11\%) w stosunku do plonu uzyskanego z roślin zdrowych. W przypadku zakażenia materiału roślinnego przez GarV-C notowano spadek ciężaru cebul wynoszący $15 \%$ oraz zmniejszenie ich średnicy o $5 \%$ (Cafrune i wsp. 2006). Podobne wyniki badań uzyskali Perotto i wsp. (2010), którzy sprawdzali wpływ porażenia GarV-A i GarV-C na ciężar cebul czosnku pospolitego odmiany Blanco. Wykazali oni również, że w przypadku dodatkowego porażenia materiału roślinnego przez wirus karłowatości cebuli (Onion yellow dwarf virus, OYDV) i/lub wirus żółtej pasiastości pora (Leek yellow stripe virus, LYSV) spadek ciężaru cebul wynosił od 25 do $43 \%$.
Bardzo rzadko rośliny czosnku pospolitego są porażane przez jeden gatunek wirusa należący do rodzaju Allexivirus. Zazwyczaj są to infekcje mieszane na co wskazują dane prezentowane przez Bos (1983), Fujisawa (1989), Walkey i Antill (1989), Walkey (1990), Conci i wsp. (1992, 2010), Van Dijk (1993), Takaichi i wsp. (1998), Majumder i wsp. (2008, 2014) oraz Kumar i wsp. (2010).

W Brazylii dominującymi gatunkami były GarV-D i GarV-A (Oliveira i wsp. 2014; Mituti i wsp. 2015), natomiast GarV-X notowano w 16,55\% badanych prób. W Grecji, Dovas i wsp. (2001) wykrywali GarV-D w 67\% testowanych prób, zaś GarV-C w $62 \%$ prób. Według Jemal i wsp. (2015) w czosnku pochodzącym z Etiopii GarV-B występuje w 17,7\% testowanych prób, a GarV-C w 4,8\%. W Polsce, Bereda (2015) wykazała, że najwięcej badanych roślin było porażonych przez GarV-X (72,91\% prób), GarV-B (71,18\% prób) i GarV-D (60,76\% prób), podczas gdy GarV-A, GarV-C i GarV-E wykrywano średnio w $18,86 \%$ prób. Ponadto autorka wskazała, że cebule czosnku pospolitego importowane z Chin, Egiptu, Hiszpanii i Meksyku znajdujące się w obrocie handlowym na terenie Polski były porażane przez GarV-A, GarV-B, GarV-C, GarV-D, GarV-E lub GarV-X. Największą liczbę zakażonych prób odnotowywano w materiale pochodzącym z Egiptu (70\%) oraz Meksyku (68\%), podczas gdy średnio w $37 \%$ badanych prób cebul pochodzących z Chin i Hiszpanii wykrywano powyższe patogeny. Najczęściej w testowanych roślinach notowano wirus D czosnku (93\% prób), zaś wirus C czosnku był obecny w zaledwie 3\% badanych prób. Podobnie Parrano i wsp. (2012) wykrywali wirus X czosnku w materiale z Chin, a Wylie i wsp. (2014) wykrywali GarV-A, GarV-B, GarV-C, GarV-D, GarV-E i GarV-X w materiale importowanym z Hiszpanii i Meksyku. Zjawisko to potwierdzają Melo-Filho i wsp. (2004) oraz Oliveira i wsp. (2014), którzy podkreślali dużą rolę importu czosnku z Europy, Azji i Argentyny w pojawianiu się zupełnie nowych, dotychczas nieznanych gatunków wirusów w różnych odległych rejonach świata, w tym przypadku na obszarze Brazylii.

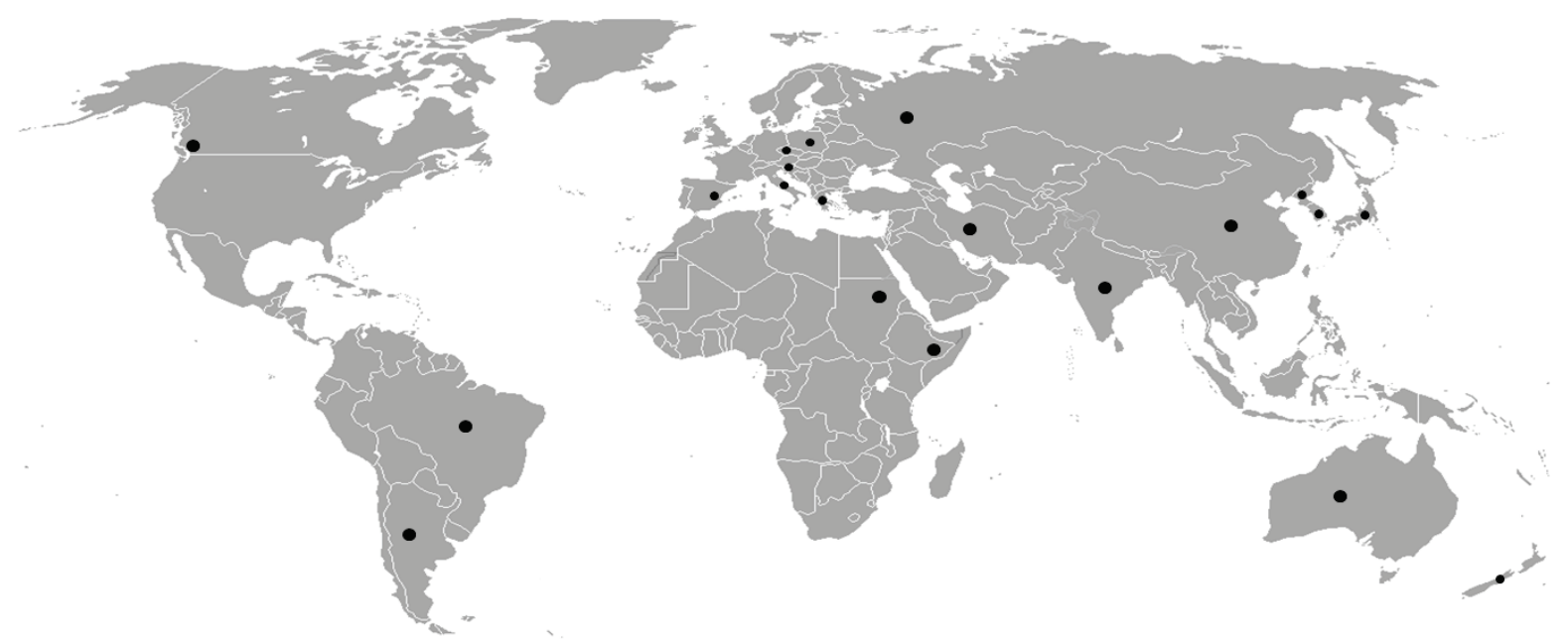

Rys. 1. Rozmieszczenie występowania allexiwirusów na świecie

Fig. 1. Distribution of allexiviruses occurrence in the world 
Wydaje się, że obecność poszczególnych gatunków allexiwirusów w badanym materiale jest dość przypadkowa. Nie obserwuje się dominacji jednego określonego gatunku wirusa, na co wskazywali także w swoich badaniach Dovas i wsp. (2001) oraz Fayad-André i wsp. (2011). Najprawdopodobniej jest to związane z przenoszeniem wirusów przez A. tulipae głównie podczas przechowywania cebul, co było już wcześniej sugerowane przez Mann i Minges (1958). Przypadkowość dominacji w uprawach czosnku pospolitego określonych gatunków allexiwirusów może być związana $\mathrm{z}$ efektywnością przenoszenia przez wektor, co dotychczas nie zostało poparte badaniami naukowymi, podobnie jak mechanizm nabywania allexiwirusów przez $A$. tulipae. Zatem dokładne wyjaśnienie mechanizmu przenoszenia allexiwirusów przez szpeciela oraz korelacji między tymi patogenami i ich wektorem jest w obecnej chwili niemożliwe. Badania potwierdzają jedynie, że w ciele wektora są obecne allexiwirusy (Van Dijk 1991), a także, że po kolonizacji przez $A$. tulipae zdrowych roślin czosnku pospolitego obserwowane są żółte smugi na zdeformowanych liściach (Kang i wsp. 2007).

Występowanie mieszanych infekcji w roślinach czosn$\mathrm{ku}$ pospolitego jest przyczyną dużych trudności w rozdzieleniu kompleksu wirusów i dokładnej identyfikacji gatunków. Zbyt wąski zakres roślin żywicielskich (rodzaj Allium) oraz roślin wskaźnikowych (Chenopodium murale) i wspólne ich przenoszenie przez szpeciela (A. tulipae) powoduje komplikacje w ustaleniu charakterystyki biologicznych właściwości.

\section{Budowa genomu allexiwirusów / Construction of allexiviruses genome}

Genom wirusów należących do rodzaju Allexivirus stanowi liniowa, pojedyncza nić, plus RNA [single stranded RNA, ssRNA (+)]. Wielkość genomu w zależności od gatunku wirusa waha się od 8000 do 9000 nukleotydów (nt) (Chen i Chen 2002; Adams i wsp. 2004). Na końcu 3'- znajduje się łańcuch poli(A) zbudowany z kilkudziesięciu nukleotydów adeninowych. Organizacja genomu jest jednakowa dla wszystkich gatunków należących do rodzaju Allexivirus.

W genomie allexiwirusów można wyróżnić sześć otwartych ramek odczytu (open reading frame, ORF) (Adams i wsp. 2004) (rys. 2).

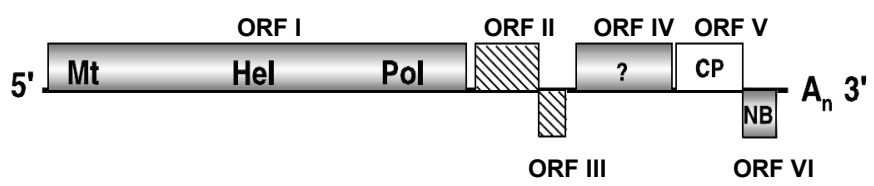

Rys. 2. Budowa genomu allexiwirusów

Fig. 2. Construction of allexiviruses genome

Pierwsza ramka odczytu, ORF I koduje białko enzymatyczne - replikazę RNA (RNA replicase) o masie cząsteczkowej (m. cz.) 174-176 kDa, posiadającą domeny polimerazy RNA zależnej od RNA (RNA-dependent RNA polymerase, RdRp) (S-G-X $\left.\mathrm{X}_{3}-\mathrm{T}-\mathrm{X}_{3}-\mathrm{N}-\mathrm{T}-\mathrm{X}_{18-37}-\mathrm{G}-\mathrm{D}-\mathrm{D}\right)$, helikazy (G-X-X-G-X-G-K-S) oraz tzw. zamek leucynowy (leucine zipper) (L-X $\left.\mathrm{X}_{6}-\mathrm{L}-\mathrm{X}_{6}-\mathrm{L}-\mathrm{X}_{6}-\mathrm{L}\right)$ (Chen i Chen 2002). Struktura tego białka jest najbardziej zbliżona do struktury replikazy RNA występującej u przedstawicieli rodzaju Potexvirus (Kanyuka i wsp. 1992).

ORF II koduje białko (m. cz. 26-27 kDa) analogiczne do białka TGB1 (triple gene block, TGB1) kodowanego przez ORF I obecnego u przedstawicieli rodzaju Carlai Potexvirus. Występowanie tej wysoce konserwatywnej domeny wiążącej, tożsamej z domeną występującą w ORF I, sugeruje że może ono pełnić funkcję NTP-zależnej DNA helikazy (NTP-dependent DNA helicase). Ponadto, białko to jest bogate w leucynę (12\%) (Zimmern 1987; Forster i wsp. 1988; Zavriev i wsp. 1991).

ORF III koduje białko (m. cz. 11-12 kDa) homologiczne do białka TGB2 (triple gene block, TGB2) carlai potexwirusów. W przypadku wirusa mozaiki koniczyny (White clover mosaic virus, WCIMV) należącego do rodzaju Potexvirus produkt tej ramki odczytu uczestniczy w przenoszeniu wirionów między komórkami gospodarza (Beck i wsp. 1991).

Białko o masie cząsteczkowej $40 \mathrm{kDa}$, kodowane przez ORF IV stanowi cechę genomu odróżniającą gatunki należące do rodzaju Allexivirus od gatunków należących do rodzaju Carla- i Potexvirus. Białko o nieznanej funkcji jest bardzo bogate w dwa aminokwasy, tj. serynę (11\%) i treoninę (11\%) (Chen i Chen 2002).

ORF V koduje białko płaszcza wirusów (coat protein, CP) (m. cz. $28 \mathrm{kDa}$ ) (Chen i Chen 2002).

ORF VI koduje białko wiążące kwasy nukleinowe (nucleic acid-binding protein, NABP) (m. cz. 11-15 kDa), które w swojej budowie posiada charakterystyczną dla gatunków należących do rodzaju Carlavirus, domenę zawierającą struktury palców cynkowych (zinc finger motif) wiążących kwasy nukleinowe regulujące replikację wirusa (Foster 1992).

Pomiędzy ORF III i ORF IV stwierdzono występowanie dodatkowej otwartej ramki odczytu, nazwanej ORF III-IV, pomimo braku obecności kodonu start (AUG). ORF III-IV koduje białko zawierające konserwatywną domenę (C-V-I-X-I-T-G-E-S-X $2-\mathrm{G}-\mathrm{C}$ ) obecną w białku TGB3 (triple gene block, TGB3) u przedstawicieli carla- i potexwirusów. Przypuszczalnie, translacja ORF III-IV może być inicjowana przez inny kodon (AUU, CUG, UUG), co jest powszechnie występującym zjawiskiem u wirusów roślinnych, np. u wirusa pasiastej mozaiki jęczmienia (Barley stripe mosaic virus, BSMV, rodzina Virgaviridae, rodzaj Hordeivirus) i wirusa łagodnej żółtaczki brzegów liści truskawki (Strawberry mild yellow edge virus, SMYEV, rodzina Alphaflexiviridae, rodzaj Potexvirus) (Petty i Jackson 1990; Jelkmann i wsp. 1992).

\section{Zróżnicowanie genetyczne populacji allexiwirusów / Genetic diversity of allexiviruses populations}

Dzięki zastosowaniu techniki RT-PCR możliwe było przeprowadzenie molekularnej charakterystyki wirusów z rodzaju Allexivirus, która objęła populacje wirusów pochodzących $\mathrm{z}$ różnych rejonów świata. Zestawienie danych dotyczących podobieństwa izolatów poszczególnych allexiwirusów przedstawiono w tabeli 1 . 
Tabela 1. Zakres podobieństwa między izolatami poszczególnych gatunków z rodzaju Allexivirus

Table 1. The range of the similarity between the isolates of each species of the genus Allexivirus

\begin{tabular}{|c|c|c|c|}
\hline $\begin{array}{l}\text { Wirus } \\
\text { Virus }\end{array}$ & $\begin{array}{c}\text { Identyczność } \\
\text { analizowanych } \\
\text { sekwencji } \\
\text { Identities } \\
\text { of analyzed } \\
\text { sequences } \\
{[\%]}\end{array}$ & $\begin{array}{l}\text { Analizowany fragment genomu/analizowana sekwencja } \\
\text { Analyzed genome fragment/analyzed sequence }\end{array}$ & $\begin{array}{l}\text { Dane literaturowe } \\
\text { References }\end{array}$ \\
\hline GarMbFV & $\begin{array}{c}72-91 \% \\
96,6 \%\end{array}$ & $\begin{array}{l}\text { białko płaszcza }(\mathrm{ORFV}) / \mathrm{nt} \text { - coat protein }(\mathrm{ORFV}) / \mathrm{nt} \\
\text { białko płaszcza }(\mathrm{ORFV}) / \mathrm{aa} \text { - coat protein }(\mathrm{ORFV}) / \mathrm{aa}\end{array}$ & $\begin{array}{l}\text { Park i wsp. (2005), Oliveira i wsp. (2014) } \\
\text { Melo-Filho i wsp. (2004) }\end{array}$ \\
\hline GarV-A & $\begin{array}{c}94-96 \% \\
81-98 \% \\
75-100 \% \\
94-99 \% \\
99 \% \\
91,7 \%\end{array}$ & $\begin{array}{l}\text { replikaza (ORFI)/aa - replicase (ORFI)/aa } \\
\text { TGBI (ORFII)/aa } \\
\text { białko płaszcza }(\mathrm{ORFV}) / \mathrm{nt} \text { - coat protein }(\mathrm{ORFV}) / \mathrm{nt} \\
\text { białko płaszcza }(\mathrm{ORFV}) / \mathrm{aa} \text { - coat protein }(\mathrm{ORFV}) / \mathrm{aa} \\
\text { białko wiążące kwasy nukleinowe }(\mathrm{ORFVI}) / \mathrm{nt} \text { - nucleic acid } \\
\text { binding protein }(\mathrm{ORFVI}) / \mathrm{nt} \\
\text { białko płaszcza i białko wiążące kwasy nukleinowe }(\mathrm{ORFV}, \\
\text { ORFVI)/nt - coat protein and nucleic acid binding protein } \\
(\mathrm{ORFV}, \mathrm{ORFVI}) / \mathrm{nt} \\
\text { ORFI, ORFII, ORFIII, ORFIV, ORFV i ORFVI/nt - ORFI, } \\
\text { ORFII, ORFIII, ORFIV, ORFV and ORFVI/nt }\end{array}$ & $\begin{array}{l}\text { Lee i wsp. (2007) } \\
\text { Gawande i wsp. (2015) } \\
\text { Koo i wsp. (2002), Oliveira i wsp. (2014) } \\
\text { Wylie i wsp. (2012) } \\
\text { Koo i wsp. (2002) } \\
\text { Mohammed i wsp. (2013) } \\
\text { Wylie i wsp. (2012) }\end{array}$ \\
\hline GarV-B & $\begin{array}{c}88-99 \% \\
83-100 \% \\
95,4 \% \\
\\
90-100 \% \\
88,8 \%\end{array}$ & $\begin{array}{l}\text { białko płaszcza (ORFV)/aa - coat protein }(\mathrm{ORFV}) / \mathrm{aa} \\
\text { białko płaszcza (ORFV)/nt- coat protein }(\mathrm{ORFV}) / \mathrm{nt} \\
\text { białko płaszcza i białko wiążące kwasy nukleinowe (ORFV, } \\
\text { ORFVI)/nt - coat protein and nucleic acid binding protein } \\
(\mathrm{ORFV}, \mathrm{ORFVI} / \mathrm{nt} \\
\text { białko wiążące kwasy nukleinowe (ORFVI)/nt - nucleic acid } \\
\text { binding protein (ORFVI)/nt } \\
\text { ORFI, ORFII, ORFIII, ORFIV, ORFV i ORFVI/nt - ORFI, } \\
\text { ORFII, ORFIII, ORFIV, ORFV and ORFVI/nt }\end{array}$ & $\begin{array}{l}\text { Wylie i wsp. (2012) } \\
\text { Oliveira i wsp. (2014), Bereda (2015) } \\
\text { Mohammed i wsp. (2013) } \\
\text { Bereda (2015) } \\
\text { Wylie i wsp. (2012) }\end{array}$ \\
\hline GarV-C & $\begin{array}{c}86-92 \% \\
69-98 \% \\
94-99 \% \\
84,1 \%\end{array}$ & $\begin{array}{l}\text { replikaza (ORFI)/aa - replicase (ORFI)/aa } \\
\text { białko płaszcza (ORFV)/nt - coat protein }(\mathrm{ORFV}) / \mathrm{nt} \\
\text { białko płaszcza (ORFV)/aa - coat protein (ORFV)/aa } \\
\text { białko płaszcza i białko wiążące kwasy nukleinowe (ORFV, } \\
\text { ORFVI)/nt - coat protein and nucleic acid binding protein } \\
(\mathrm{ORFV,} \mathrm{ORFVI)/nt} \\
\text { ORFI, ORFII, ORFIII, ORFIV, ORFV i ORFVI/nt - ORFI, } \\
\text { ORFII, ORFIII, ORFIV, ORFV and ORFVI/nt }\end{array}$ & $\begin{array}{l}\text { Lee i wsp. (2007) } \\
\text { Oliveira i wsp. (2014) } \\
\text { Melo-Filho i wsp. (2004), Wylie i wsp. (2012) } \\
\text { Mohammed i wsp. (2013) }\end{array}$ \\
\hline GarV-D & $\begin{array}{c}85-100 \% \\
89-100 \% \\
87-100 \% \\
87,6 \%\end{array}$ & $\begin{array}{l}\text { białko płaszcza (ORFV)/nt - coat protein }(\mathrm{ORFV}) / \mathrm{nt} \\
\text { białko płaszcza (ORFV)/aa - coat protein }(\mathrm{ORFV}) / \mathrm{aa} \\
\text { białko wiążące kwasy nukleinowe (ORFVI)/nt - nucleic acid } \\
\text { binding protein (ORFVI)/nt } \\
\text { ORFI, ORFII, ORFIII, ORFIV, ORFV i ORFVI/nt - ORFI, } \\
\text { ORFII, ORFIII, ORFIV, ORFV and ORFVI/nt }\end{array}$ & $\begin{array}{l}\text { Koo i wsp. (2002), Lanzoni i wsp. (2006), } \\
\text { Oliveira i wsp. (2014), Bereda (2015) } \\
\text { Melo-Filho i wsp. (2004), Wylie i wsp. (2012) } \\
\text { Koo i wsp. (2002), Bereda (2015) } \\
\text { Wylie i wsp. (2012) }\end{array}$ \\
\hline GarV-E & $95 \%$ & replikaza (ORFI)/aa - replicase (ORFI)/aa & Lee i wsp. (2007) \\
\hline GarV-X & $\begin{array}{c}85-93 \% \\
80-100 \% \\
90,3 \%\end{array}$ & $\begin{array}{l}\text { replikaza }(\mathrm{ORFI}) / \mathrm{aa} \text { - replicase }(\mathrm{ORFI}) / \mathrm{aa} \\
\text { białko płaszcza }(\mathrm{ORFV}) / \mathrm{nt} \text { - coat protein }(\mathrm{ORFV}) / \mathrm{nt} \\
\text { białko płaszcza i białko wiążące kwasy nukleinowe }(\mathrm{ORFV}, \\
\text { ORFVI)/nt - coat protein and nucleic acid binding protein } \\
(\mathrm{ORFV}, \mathrm{ORFVI} / \mathrm{nt} \\
\text { białko wiążące kwasy nukleinowe (ORFVI)/nt - nucleic acid } \\
\text { binding protein }(\mathrm{ORFVI}) / \mathrm{nt} \\
\text { pełen genom/nt - whole genom/nt }\end{array}$ & $\begin{array}{l}\text { Lee i wsp. (2007) } \\
\text { Bereda (2015) } \\
\text { Mohammed i wsp. (2013) }\end{array}$ \\
\hline
\end{tabular}

Wykonane przez Chen i wsp. (2001) analizy filogenetyczne pełnej sekwencji genomu chińskiego izolatu GarV-X-YH wykazały, że była ona najbardziej podobna do pełnej sekwencji genomu koreańskiego izolatu GarV-X $(90,2 \%)$, a różniła się o około 200 nt. Zmiana ta na wysokości ORF IV została uznana na podstawie porównania sekwencji nukleotydów genomu powyższych izolatów wirusa z pełnymi sekwencjami genomu izolatów GarV-X dostępnymi w banku genów za delecję występującą w sekwencji nukleotydów genomu izolatu koreańskiego.

Wyraźnie wyższy procent identyczności otrzymywano po analizie filogenetycznej prowadzonej w oparciu o sekwencje nukleotydowe i aminokwasowe różnych fragmentów genomu poszczególnych gatunków allexiwirusów. 
Według Lee i wsp. (2007) poziom identyczności sekwencji aminokwasów ORF I między koreańskimi izolatami GarV-A, GarV-C, GarV-E i GarV-X a izolatami japońskimi i chińskimi wirusów zdeponowanymi w banku genów wahał się od 85 do $96 \%$.

Gawande i wsp. (2015) uzyskali dla indyjskich izolatów wirusa A czosnku od 80 do $88 \%$ identyczności na poziomie nt oraz od 81 do $98 \%$ identyczności na poziomie aa genu kodującego TGB1 w stosunku do homologicznej sekwencji izolatów wirusa z Australii.

Analizy filogenetyczne przeprowadzone przez Wylie i wsp. (2012a) oparte na sekwencjach nukleotydów genu kodującego: TGB1, TGB2 i białko o masie cząsteczkowej $40 \mathrm{kDa}$ australijskich izolatów GarV-A, GarV-B, GarV-C i GarV-D oraz izolatów pochodzących z Azji, Ameryki Południowej i Europy dawały identyczność, odpowiednio 76,8-90,0, 79,5 i 93,8\%.

Wśród prac dotyczących zróżnicowania genetycznego populacji allexiwirusów przeważają te dotyczące pokrewieństwa sekwencji nt i aa genu kodującego CP i NABP izolatów pochodzących z Azji (Korea, Chiny, Japonia) oraz izolatów z Europy (Włochy, Polska), Australii, Afryki (Sudan) i Ameryki Południowej (Brazylia).

Jak podaje Lanzoni i wsp. (2006) poziom identyczności sekwencji nukleotydów genu kodującego CP między włoskimi izolatami GarV-D a koreańskim i japońskim izolatem wirusa wyniósł odpowiednio 97,2-99,6 i 95,4\%. Wyraźnie wyższy poziom identyczności obserwowali Wylie i wsp. (2014) dla sekwencji aa w tym obszarze między australijskimi a koreańskimi, japońskimi, meksykańskimi oraz argentyńskimi izolatami GarV-A, GarV-B, GarV-C i GarV-D, który był w zakresie, odpowiednio 94-99, 88-99, 94-99 i 89-100\%.

Brazylijskie izolaty GarV-A, GarV-B, GarV-C i GarV-D wykazywały najwyższy stopień identyczności (89-90\%) sekwencji nukleotydów genu kodującego CP w stosunku do australijskiego izolatu GarV-A oraz 95-98\% identyczności w stosunku do izolatu z Korei, Japonii i Australi. Dla izolatów GarV-B poziom identyczności w omawianym obszarze wynosił 83-90\% w stosunku do izolatu z Korei i $90 \%$ w stosunku do izolatu z Australii. Brazylijskie izolaty GarV-C tworzyły grupę o wysokiej identyczności (97-98\%) z izolatem z Japonii oraz Australii. W przypadku izolatów GarV-D sekwencja nukleotydów genu kodującego CP wykazała 97\% identyczności do homologicznej sekwencji australijskiego izolatu oraz 95\% identyczności do sekwencji izolatu pochodzącego z Korei (Oliveira i wsp. 2014).

Wyniki analiz filogenetycznych przeprowadzonych przez Melo-Filho i wsp. (2004) wskazywały, że sekwencja aminokwasów CP brazylijskiego izolatu GarV-C była w 95\% identyczna z japońskim izolatem GarV-C. Procent identyczności sekwencji aminokwasów CP brazylijskiego izolatu GarMbFV w stosunku do argentyńskiego izolatu oszacowano na $96,6 \%$. Natomiast poziom podobieństwa sekwencji aa w tym obszarze między brazylijskim izolatem GarV-D a sekwencjami aa japońskiego izolatu wynosił $96,8 \%$.

Dla koreańskiego izolatu GarV-A(K) i japońskiego izolatu GarV-A identyczność sekwencji nukleotydów genu kodującego CP i NABP wynosiła, odpowiednio 100 i 99\%.
W przypadku koreańskiego izolatu GarV-D(K) sekwencja nt genu kodującego CP była identyczna w 98\%, a sekwencja nt genu kodującego NABP w $87 \%$ w stosunku do homologicznych sekwencji nt japońskiego izolatu GarV-D (Koo i wsp. 2002).

Mohammed i wsp. (2013) przeprowadzili analizę filogenetyczną sekwencji nukleotydów i aminokwasów genu kodującego CP i genu kodującego NABP między sudańskimi a koreańskimi, chińskimi i australijskimi izolatami GarV-A, GarV-B, GarV-C i GarV-X. Identyczność sekwencji nt genu kodującego CP i NABP wyniosła 91,7\% dla GarV-A, 95,4\% dla GarV-B, 84,1\% dla GarV-C i 90,3\% dla GarV-X. Analiza sekwencji aminokwasów genu kodującego CP i NABP izolatów GarV-A, GarV-B, GarV-C i GarV-X wskazywała na procent identyczności wahający się od 85 do 98,1\%.

W Polsce, Bereda (2015) jako pierwsza wykonała analizy: zmienności genetycznej, występowania miejsc rekombinacji oraz presji selekcyjnej wzdłuż genów kodujących CP i NABP krajowej populacji izolatów GarV-B, GarV-D i GarV-X.

Identyczność kompletnych sekwencji nukleotydów genu kodującego CP i NABP polskich izolatów GarV-B W stosunku do zagranicznych izolatów dostępnych w banku genów wyniosła, odpowiednio $87-100 \%$ i $90-100 \%$, a sekwencje aa tych genów były identyczne w zakresie 93-100\% (CP) oraz 91-100\% (NABP). Polskie izolaty wirusa znalazły się w jednej grupie wraz z izolatami z Azji (Japonia, Korea), Ameryki Południowej (Argentyna, Brazylia) oraz Australii. Analiza presji selekcyjnej wzdłuż genów kodujących CP i NABP izolatów GarV-B z użyciem modeli REL, FEL i SLAC nie wskazała kodonów będących pod działaniem pozytywnej presji dla żadnego z dwóch badanych genów, co świadczyło, że oba geny znajdują się pod działaniem oczyszczającej presji selekcyjnej, warunkującej niezmienność łańcucha sekwencji aminokwasów. Stopień identyczności $85-100 \%$ dla sekwencji nt oraz 91-100\% dla sekwencji aa otrzymano, gdy analizowano sekwencje nt i aa CP polskich izolatów w zestawieniu ze wszystkimi dostępnymi w banku genów izolatami GarV-D. W przypadku genu kodującego NABP wirusa porównanie wykazywało identyczność $89-100 \%$ na poziomie nt oraz $88-100 \%$ na poziomie aa. Przeprowadzone analizy filogenetyczne oparte na sekwencjach aminokwasów CP izolatów GarV-D wykazały ich podział na dwie grupy filogenetyczne. $W$ jednej grupie znajdowały się izolaty z Polski razem z izolatami z Korei, Argentyny, Japonii i jednym izolatem $z$ Brazylii, natomiast druga tworzyły izolaty z Brazylii i Australii. Drzewa skonstruowane na podstawie sekwencji aminokwasów NABP izolatów GarV-D również wykazały podział badanych izolatów na dwie grupy: grupa I - izolaty polskie, koreańskie, japońskie $\mathrm{i}$ argentyńskie o wysokim pokrewieństwie filogenetycznym, natomiast w grupie II znalazł się tylko jeden izolat $\mathrm{z}$ Australii. Analiza występowania miejsc rekombinacji oraz analiza presji selekcyjnej wzdłuz genów kodujących CP i NABP polskich izolatów GarV-D wykazała obecność punktów rekombinacji w obrębie nukleotydów 501-504 w sekwencji genu kodującego CP. W przypadku sekwencji nukleotydów genu kodującego NABP obecność rekombinacji została stwierdzona tylko 
przez jeden algorytm - SBP. Przeprowadzona analiza presji selekcyjnej wytypowała, wzdłuż genu kodującego $\mathrm{CP}$, dwa kodony będące pod działaniem pozytywnej presji selekcyjnej. Jednakże przewaga kodonów będących pod wpływem negatywnej presji selekcyjnej świadczy o stabilności genetycznej populacji GarV-D. Analiza presji selekcyjnej wykonana wzdłuż genu kodującego NABP również wskazała, że w sekwencji nukleotydów kodujących białko wiążące kwasy nukleinowe izolatów GarV-D występują kodony, w których większość substytucji nukleotydowych nie wpływa na zmianę sekwencji aminokwasów w tym białku. Wytypowano tylko jeden kodon (kodon 41) będący pod działaniem pozytywnej presji selekcyjnej. Interesującym jest, że kodon 41 stanowi część konserwatywnej domeny wiążącej kwasy nukleinowe o budowie palców cynkowych (zinc finger motif). Występowanie tego motywu jest charakterystyczne dla przedstawicieli rodzaju Allexivirus oraz Carlavirus (Foster 1992). Domena wiążąca kwasy nukleinowe o budowie palców cynkowych jest strukturą niezwykle stabilną genetycznie. Występowanie pozytywnej selekcji może świadczyć o adaptacji populacji wirusa do zmieniających się warunków. Dalsze prace obejmujące poznanie funkcji kodonu 41 mogłyby być bardzo przydatne w określeniu nowych funkcji białka wiążącego kwasy nukleinowe. Zhou i wsp. (2006) wykazali, że białko wiążące kwasy nukleinowe wirusa A winorośli (Grapevine virus A, GVA) odpowiada za hamowanie procesu wyciszania RNA. W przypadku GarV-X ustalono niskie zróżnicowanie populacji polskich izolatów (97-100\% dla sekwencji nt CP oraz 98-100\% dla sekwencji aa CP; 93-100\% dla sekwencji nt NABP oraz $91-100 \%$ dla sekwencji aa NABP). Porównanie sekwencji nt i aa CP (80-100\% dla sekwencji nt i 89-100\% dla sekwencji aa) i NABP (87-100\% dla sekwencji nt i aa) między polskimi izolatami wirusa a izolatami zdeponowanymi w banku genów wykazało dużo wyższe zróżnicowanie wśród badanych izolatów. Przeprowadzona analiza drzew filogenetycznych opartych na sekwencjach nt $\mathrm{i}$ aa białka płaszcza była zbieżna $\mathrm{z}$ analizą zmienności genetycznej, ponieważ wykazała, że polska populacja izolatów GarV-X stanowi odrębną grupę od reszty izolatów wirusa zdeponowanych w banku genów. Oddzielną grupę tworzyły także izolaty pochodzące $\mathrm{z}$ Indii, natomiast izolaty pochodzące $\mathrm{z}$ Włoch, Chin, USA, Australii, Brazylii, Meksyku i Hiszpanii utworzyły grupę wysoce podobną. Bardzo podobnie skonstruowane drzewo uzyskano w oparciu o sekwencje aminokwasów CP. Badania oparte na sekwencji nukleotydów genu kodującego NABP i na sekwencji aminokwasów NABP wykazały odrębność polskiej populacji izolatów od innych izolatów GarV-X dostępnych w banku genów, jednakże zróżnicowanie między sekwencjami nt $\mathrm{i}$ aa izolatów GarV-X było zbyt niskie i nie pozwoliło na powstanie wystarczającej odległości między poszczególnymi topologiami drzew dla utworzenia oddzielnych grup. Wyniki analizy presji selekcyjnej przeprowadzonej wzdłuż genu kodującego białko płaszcza i genu kodującego białko wiążące kwasy nukleinowe izolatów GarV-X wykazały, że presja selekcyjna działająca na te geny ma rolę oczyszczającą, ponieważ jedynie wzdłuż genu kodującego NABP odnotowano negatywną presję selekcyjną działającą na jeden z kodonów.
W przypadku GarMbFV poziom identyczności sekwencji nukleotydów genu kodującego CP izolatu GarMbFV analizowanej sekwencji między japońskim i koreańskim izolatem GarMbFV wyniósł $86 \%$ (Park i wsp. 2005). Melo-Filho i wsp. (2004) określili poziom podobieństwa między sekwencją aminokwasów CP izolatu argentyńskiego GarMbFV a sekwencjami aminokwasów CP brazylijskich izolatów na 96,6\%.

Wyniki prezentowane przez Chen i wsp. (2001), Koo i wsp. (2002), Melo-Filho i wsp. (2004), Lanzoni i wsp. (2006), Lee i wsp. (2007), Wylie i wsp. (2012a), Mohammed i wsp. (2013), Oliveira i wsp. (2014), Wylie i wsp. (2014), Bereda (2015) oraz Gawande i wsp. (2015) dotyczące zmienności genetycznej w obrębie populacji różnych gatunków allexiwirusów świadczą o braku korelacji między pochodzeniem geograficznym izolatów a ich profilem genetycznym. Zdaniem Koo i wsp. (2002), Melo-Filho i wsp. (2004) oraz Wylie i wsp. (2014) to wegetatywny sposób rozmnażania czosnku pospolitego i jednoczesna wymiana materiału roślinnego przede wszystkim z krajów azjatyckich do Europy może przyczyniać się do dużej zmienności obserwowanej $\mathrm{w}$ populacji poszczególnych gatunków allexiwirusów pochodzących $\mathrm{z}$ tego samego kraju, bądź nawet tego samego pola uprawnego. Przypuszczalnie może to thumaczyć wysoką zmienność wykazaną wśród populacji różnych gatunków tych wirusów.

Według Chen i wsp. (2001) przyczyn dużej zmienności genetycznej populacji wirusów należy szukać w występowaniu infekcji mieszanych, co sprzyja interakcji między różnymi genotypami izolatów tego samego gatunku wirusa lub izolatów gatunków blisko spokrewnionych, np. gatunków należących do rodzaju Allexivirus. Jednakże analizowane przez Beredę (2015) populacje polskich izolatów GarV-X wydają się być stabilne, co może było skutkiem analizy jedynie 14 izolatów wirusa. $Z$ drugiej strony wysoka stabilność genetyczna jest domeną gatunków wirusów posiadających wektor i podyktowana jest koniecznością utrzymania niezmiennej budowy struktur w białkach, które uczestniczą w nabywaniu cząstek wirusa przez wektor (García-Arenal i wsp. 2001). Zmiany w sekwencjach aminokwasów tych białek mogłyby doprowadzić do znacznych strat $\mathrm{w}$ efektywności przenoszenia wirusa, co zostało udowodnione nawet $\mathrm{w}$ przypadku wirusów przenoszonych nietrwale przez mszyce (Power 2000; Matoušek i wsp. 2009). W każdej populacji wirusów obserwuje się występowanie wariantów genetycznych, jednak rzadko stają się one dominujące w stosunku do znanej populacji. Wynika to $\mathrm{z}$ faktu, iż każda zmiana w genomie warunkująca zwiększoną patogeniczność powoduje powstanie mutacji przyczyniających się do pogorszenia zdolności adaptacyjnych w polu i/lub u nowych gospodarzy (García-Arenal i McDonald 2003).

\section{Diagnostyka roślin porażonych przez allexiwirusy Diagnostic the plants infected with viruses belong to Allexivirus genus}

Diagnostyka poszczególnych gatunków wirusów należących do rodzaju Allexivirus jest niezwykle trudna ze względu na obecność w roślinach infekcji mieszanych 
składających się z różnych gatunków wirusów. Biotesty, w przypadku tej grupy patogenów, nie mają zastosowania ze względu na między innymi zbyt wąski zakres roślin wskaźnikowych (Bos 1983). Wyniki wstępnych prac prowadzonych przez autorów niniejszego artykułu wykazały, że po wykonaniu mechanicznej inokulacji sokiem pochodzącym z roślin porażonych przez allexiwirusy na komosie ryżowej (Chenopodium quinoa L.) obserwowano objawy lokalne, a na komosie murowej (Chenopodium murale L.) objawy systemiczne. Próba wyizolowania wirusów z tych roślin wskazywała, że sprawcami obserwowanych zmian mogły być także carla- i potywirusy występujące w roślinach źródłowych.

Mało skuteczne w przypadku allexiwirusów jest również ich wykrywanie i identyfikacja z użyciem technik elektronomikroskopowych. Diekmann (1997) stwierdził, że badania z użyciem mikroskopu elektronowego pozwalają na wyróżnienie cząstek allexiwirusów spośród wirionów gatunków należących do rodzaju Carla- i Potyvirus, jednakże niemożliwym jest odróżnienie poszczególnych gatunków tych patogenów. Podobnie Koo i wsp. (2002), Cafrune i wsp. (2006), Lee i wsp. (2007) oraz Bereda (2015) wykorzystywali mikroskop elektronowy jedynie jako narzędzie do potwierdzenia obecności w badanych roślinach allexiwirusów bez szczegółowej identyfikacji gatunków.

Testy serologiczne powszechnie stosowane w wirusologii roślin, zwłaszcza test ELISA, bywają również trudne, ze względu na kłopoty $\mathrm{z}$ otrzymaniem specyficznych dla danego gatunku surowic (Helguera i wsp. 1997; Lu i wsp. 2008). Obecnie rynek komercyjny oferuje zestawy do wykrywania jedynie trzech spośród ośmiu gatunków allexiwirusów: GarV-A, GarV-B i GarV-C, dlatego zasadnym jest wykorzystywanie techniki opartej na reakcji łańcuchcowej polimerazy (Takaichi i wsp. 1998; Tsuneyoshi i wsp. 1998). Jednakże i ta technika w przypadku allexiwirusów ma pewne ograniczenia. Wysokie podobieństwo sekwencji nukleotydów poszczególnych fragmentów genomu tych wirusów staje się przyczyną trudności w zaprojektowaniu wysoce specyficznych starterów (Adams i wsp. 2004).

Poszukując nowych narzędzi diagnostycznych, Bereda (2015), wprowadzając własne modyfikacje zaproponowała wykorzystanie techniki hybrydyzacji kwasów nukleinowych typu dot-blot, do wykrywania GarV-D, GarV-E i GarV-X w roślinach czosnku pospolitego. Analiza sygnału chemiluminescencji wykazała powinowactwo sondy w stosunku do RNA każdego z sześciu badanych izolatów GarV-D, GarV-E i GarV-X. Dla prób kontroli negatywnej nie obserwowano sygnału chemiluminescencji. Co istotne, metoda ta nie wymaga użycia specjalistycznego sprzętu. Może, więc być $\mathrm{z}$ powodzeniem stosowana w większości laboratoriów. Otrzymane wyniki mają bardzo ważny aspekt praktyczny, szczególnie dla diagnostyki GarV-D, GarV-E i GarV-X, dla których nie ma komercyjnie dostępnych zestawów do testu ELISA.

\section{Podziękowanie / Acknowledgements}

Projekt został sfinansowany ze środków Narodowego Centrum Nauki przyznanych na podstawie decyzji numer DEC-2012/07/N/NZ9/00037.

\section{Literatura / References}

Adams M.J., Antoniw J.F., Bar-Joseph M., Brunt A.A., Candresse T., Foster G.D., Martelli G.P., Milne R.G., Fauquet C.M. 2004. The new plant virus family Flexiviridae and assessment of molecular criteria for species demarcation. Archives of Virology 149: $1045-1060$.

Beck D.L., Guilford P.J., Voot D.M., Andersen M.T., Forster R.L.S. 1991. Triple gene block proteins of white clover mosaic potexvirus are required for transport. Virology 183: 695-702.

Bereda M. 2015. Charakterystyka allexiwirusów - patogenów roślin czosnku (Allium sativum L.). Praca doktorska. Samodzielny Zakład Fitopatologii. Szkoła Główna Gospodarstwa Wiejskiego w Warszawie, 227 ss.

Bos L. 1983. Viruses and virus diseases of Allium species. Acta Horticulturae 127: 11-29.

Cafrune E.E., Balzarini M., Conci V.C. 2006. Changes in the concentration of an Allexivirus during the crop cycle of two garlic cultivars. Plant Disease 90 (10): 1293-1296.

Chen J., Chen J. 2002. Genome organization and phylogenetic tree analysis of Garlic virus E, a new member of genus Allexivirus. Chinease Science Bulletin 47 (1): 33-37.

Chen J., Chen J.P., Adams M.J. 2001. Molecular characterisation of a complex mixture of viruses in garlic with mosaic symptoms in China. Archives of Virology 146: 1841-1853.

Chodorska M., Paduch-Cichal E., Kalinowska E., Szyndel M.S. 2014. Assessment of Allexiviruses infection in garlic plants in Poland. Acta Scientiarum Polonorum, Hortorum Cultus 13 (2): 176-186.

Conci V.C., Canavelli A.E., Balzarini M.G. 2010. The distribution of garlic viruses in leaves and bulbs during the first year of infection. Journal of Phytopathology 158: 186-193.

Conci V.C., Nome S.F., Milne R.G. 1992. Filamentous viruses of garlic in Argentina. Plant Disease 76: 594-596.

Diekmann M. 1997. FAO/IPGRI Technical guidelines for the safe movement of germplasm. Allium spp. Food and Agriculture Organization of the United Nations, Rome/International Plant Genetic Resources Institute, Rome, p. 18.

Dovas C.I., Hatziloukas E., Salomon R., Barg E., Shiboleth Y., Katis N.I. 2001. Incidence of viruses infecting Allium spp. in Greece. Phytopathology 149: 1-7.

Dovas C.I., Volvas C. 2003. Viruses infecting Allium spp. in southern Italy. Journal of Plant Pathology 85, p. 135.

Etoh T. 1985. Studies on the sterility in garlic Allium sativum L. Memoirs of Faculty of Agriculture Kagawa University 21: 7-132.

FAO 2011. FAO Statistical Yearbook 2010. Food and Agriculture Organization (FAO), Rome, Italy. 
Fayad-André M.S., Dusi A.N., Resende R.O. 2011. Spread of viruses in garlic fields cultivated under different agricultural production systems in Brazil. Tropical Plant Pathology 36 (6): 341-349.

Fidan H., Çağlar B.K., Baloğlu S., Yılmaz M.A. 2015. Urginea maritime (L.) is a new host of Allexivirus group on onion and garlic plants in Turkey. Acta Horticulturae 1002: 309-312.

Forster R.L.S., Bevan M.W., Harbison S.A., Gardner R.C. 1988. The complete nucleotide sequence of the Potexvirus white clover mosaic virus. Nucleic Acids Research 16: 291-303.

Foster G.D. 1992. The structure and expression of the genome of carlaviruses. Research in Virology 143: 103-112.

Fujisawa J. 1989. Loss of garlic yield by double infection of garlic viruses. Agriculture \& Horticulture 64: 737-741.

García-Arenal F., Fraile M., Malpica J.M. 2001. Variability and genetic structure of plant virus populations. Annual Review of Phytopathology 39: 157-186.

García-Arenal F., McDonald B.A. 2003. An analysis of the durability of resistance to plant viruses. Phytopathology 93: 941-952.

Gawande S.J., Gurav V.S., Ingle A.A., Gopal J. 2015. First report of Garlic virus A in garlic from India. Plant Disease 99 (9), p. 1288.

Gieck S.L., Hamm P.B., David N.L., Pappu H.R. 2009. First report of Garlic virus $B$ and Garlic virus D in garlic in the Pacific Northwest. Plant Disease 93 (4), p. 431.

Helguera M., Bravo-Almonacid F., Kobayashi K., Rabinowicz P.D., Conci V., Mentaberry A. 1997. Immunological detection of a GarV-type virus in Argentine garlic cultivars. Plant Disease 81: 1005-1010.

Hillman B.I., Lawrence D.M. 1995. Carlaviruses. p. 35-50. In: "Pathogenesis and Host Specificity in Plant Diseases, Histopathological, Biochemical, Genetic and Molecular Bases. Vol III: Viruses and Viroids" (R.P. Singh, U.S. Singh, K. Kohmoto, eds). Pergamon Press, London.

Jelkmann W.E., Maiss E., Martin R.R. 1992. The nucleotide sequence and organization of strawberry mild edge-associated potexvirus. Journal of General Virology 73: 475-479.

Jemal K., Abraham A., Feyissa T. 2015. The occurrence and distribution of four viruses on garlic (Allium sativum L.) in Ethiopia. International Journal of Basic and Applied Sciences 4 (1): 5-11.

Kang S.G., Bong J.K., Eun T.L., Moo U.C. 2007. Allexivirus transmitted by eriophyoid mites in garlic plants. Journal of Microbiology and Biotechnology 17: 1833-1840.

Kanyuka K.V., Vishnichenko V.K., Levay K.E., Kondrikov D.Y., Ryabov E.V., Zavriev S.K. 1992. Nucleotide sequence of Shallot virus $X$ RNA reveals a 5-proximal cistron closely related to those of potexviruses and a unique arrangement of the 3-proximal cistrons. Journal of General Virology 73: 2553-2560.

King A.M.Q., Adams M.J., Carstens E.B., Lefkowitz E.J. 2012. Virus taxonomy: classification and nomenclature of viruses. Ninth report of the International Committee on Taxonomy of Viruses. Elsevier Academic Press, Amsterdam, 1327 pp.

Klukáčková J., Navrátil M., Duchoslav M. 2007. Natural infection of garlic (Allium sativum L.) by viruses in the Czech Republic. Journal of Plant Diseases Protection 114 (3): 97-100.

Koo B.J., Kang S.G., Chang M.U. 2002. Survey of garlic virus disease and phylogenetic characterization of garlic viruses of the genus Allexivirus isolated in Korea. Journal of Plant Pathology 18: 237-243.

Kryczyński S. 2010. Wirusologia roślinna. PWN, Warszawa, 375 ss.

Kumar S., Baranwal V.K., Joshi S., Arya M., Majumder S. 2010. Simultaneous detection of mixed infection of Onion yellow dwarf virus and an Allexivirus in RT-PCR for ensuring virus free onion bulbs. Indian Journal of Virology 21: 64-68.

Lanzoni C., Ratti C., Turina M., Pisi A., Tedeschi P., Autonell C.R. 2006. Molecular characterisation of Allexiviruses from garlic in Italy. Journal of Plant Pathology 88, p. 47.

Lee E.T., Koo B.J., Jung J.H., Chang M.U., Kang S.G. 2007. Detection of Allexiviruses in the garlic plants in Korea. Journal of Plant Pathology 23 (4): 266-271.

Lu Y.W., Chen J., Zheng H.Y., Adams M.J., Chen J.P. 2008. Serological relationships among the over-expressed coat proteins of Allexiviruses. Journal of Phytopathology 156: 251-255.

Majumder S., Baranwal V.K. 2014. Simultaneous detection of four garlic viruses by multiplex reverse transcription PCR and their distribution in Indian garlic accessions. Journal of Virology Methods 202: 34-38.

Majumder S., Baranwal V.K., Joshi S. 2008. Simultaneous detection of Onion yellow dwarf virus and Garlic latent virus in infected leaves and cloves of garlic by duplex RT-PCR. Journal of Plant Pathology 90: 369-372.

Mann L.K., Minges P.A. 1958. Growth and bulbing of garlic (Allium sativum L.) in response to storage temperature of planting day length and planting date. Hilgardia 27: 385-419.

Matoušek J., Schubert J., Dědic P. 2009. Complementation analysis of triple gene block of Potato virus $S$ (PVS) revealed its capability to support systemic infection and aphid transmissibility of recombinant Potato virus X. Virus Research 146: 81-88.

Mavric I., Ravnikar M. 2005. A carlavirus serologically closely related to Carnation latent virus in Slovenian garlic. Acta Agriculturae of Slovenia 85: 343-349.

Melo-Filho P.A., Nagata T., Dusi A.N., Buso J.A., Torres A.C., Eiras M., Resende R.O. 2004. Detection of three Allexivirus species infecting garlic in Brazil. Pesquisa Agropecuária Brasileira 39 (8): 735-740.

Mituti T., Moura M.F., Marubayashi J.M., Oliveira M.L., Imaizumi V.M., Sakate R.K., Pavan M.A. 2015. Survey of viruses belonging to different genera and species in noble garlic in Brazil. Scientia Agricola 72 (3): 278-281.

Mohammed H.S., Zicca S., Manglli A., Mohamed M.E., El Siddig M.A.R., El Hussein A.A., Tomassoli L. 2013. Occurrence and phylogenetic analysis of Potyviruses, Carlaviruses and Allexiviruses in garlic in Sudan. Journal of Phytopathology 161 (9): $642-650$.

Oliveira M.L., De Marchi D.R., Mituti T., Pavan M.A., Krause-Sakate R. 2014. Identification and sequence analysis of five allexiviruses species infecting garlic crops in Brazil. Tropical Plant Pathology 39 (6): 483-489.

Park K.S., Bae Y.J., Jung E.J., Kang S.J. 2005. RT-PCR-based detection of six garlic viruses and their phylogenetic relationships. Journal of Microbiological Biotechnology 15: 1110-1114.

Parrano L., Afunian M., Pagliaccia D., Douhan G., Vidalakis G. 2012. Characterization of viruses associated with garlic plants propagated from different reproductive tissues from Italy and other geographic regions. Phytopathologia Mediterranea 51 (3): 549-565.

Perotto M.C., Cafrune E.E., Conci V.C. 2010. The effect of additional viral infections on garlic plants initially infected with Allexiviruses. European Journal of Plant Pathology 126 (4): 489-495. 
Petty I.T.D., Jackson A.O. 1990. Two forms of the major barley stripe mosaic virus nonstructural protein are synthesized in vivo from alternative initiation codons. Virology 177: 829-832.

Power A.G. 2000. Insect transmission of plant viruses: a constraint on virus variability. Current Opinion in Plant Biology 3: 336-340.

Razvjazkina G.M. 1971. Das Zwiebelmosaikvirus und seine Verbreitung im Freiland. Tagungs-Berichte der Deutschen Akademie der Landwirtschaftswissenschaften (Berlin) 115: 69-76.

Shahraeen N., Lesemann D.E., Ghotbi T. 2008. Survey for viruses infecting onion, garlic and leek crop in Iran. EPPO Bulletin 38 (1): $131-135$.

Simon P.W., Jenderek M.M. 2003. Flowering, seed production and the genesis of garlic breeding. Plant Breeding Reviews 32: $211-244$.

Singh P., Prabha K., Jain R.K., Baranwal V.K. 2014. N-terminal in coat protein of Garlic virus $X$ is indispensible for its serological detection. Virus Genes 48 (1): 128-132.

Sumi S., Matsumi T., Tsuneyoshi T. 1999. Complete nucleotide sequences of Garlic viruses $A$ and $C$, members of the newly ratified genus Allexivirus. Archives of Virology 144: 1819-1826.

Sumi S., Tsuneyoshi T., Furutani H. 1993. Novel rod-shaped viruses isolated from garlic, Allium sativum, possessing a unique genome organization. Journal of General Virology 74: 1879-1885.

Tabanelli D., Bertaccini A., Bellardi M.G. 2004. Molecular detection of filamentous viruses infecting garlic from different geographic origins. Journal of Plant Pathology 86 (4), p. 335.

Takaichi M., Yamamoto M., Nagakubo T., Oeda K. 1998. Four garlic viruses identified by reverse transcription-polymerase chain reaction and their regional distribution in northern Japan. Plant Disease 82: 694-698.

Tsuneyoshi T., Matsumi T., Natsuaki K.T., Sumi S. 1998. Nucleotide sequence analysis of virus isolates indicates the presence of three Potyvirus species in Allium plants. Archives of Virology 143: 97-113.

Van Dijk P. 1991. Mite-borne virus isolates from cultivated Allium species and their classification into two new rymoviruses in the family Potyviridae. Netherlands Journal of Plant Pathology 97: 381-399.

Van Dijk P. 1993. Survey and characterization of potyviruses and their strains in Allium species. Netherlands Journal of Plant Pathology 99: 1-48.

Van Dijk P., Van der Vlugt R.A.A. 1994. New mite-borne virus isolates from rakkyo, shallot and wild leek species. European Journal of Plant Pathology 100: 269-277.

Walkey D.G.A. 1990. Virus diseases. p. 191-212. In: “Onions and Allied Crops”, Vol. II (H.D. Rabinowitch, J.L. Brewster, eds.). CRC Press, Boca Raton, FL.

Walkey D.G.A., Antill D.N. 1989. Agronomic evaluation of virus-free and virus infected garlic (Allium sativum L.). Journal of Horticulturae Science 64: 53-60.

Ward L.I., Perez-Egusquiza Z., Fletcher J.D., Clover G.R.G. 2009. A survey of viral diseases of Allium crops in New Zealand. Australasian Plant Pathology 38: 533-539.

Wylie S.J., Li H., Jones M.G.K. 2012a. Phylogenetic analysis of allexiviruses identified on garlic from Australia. Australasian Plant Disease Notes 7: 23-27.

Wylie S.J., Li H., Saqib M., Jones M.G.K. 2014. The global trade in fresh produce and the vagility of plant viruses: a case study in garlic. PLoS ONE 9 (8): e105044.

Wylie S.J., Luo H., Li H., Jones M.G. 2012b. Multiple polyadenylated RNA viruses detected in pooled cultivated and wild plant samples. Archives of Virology 157 (2): 271-284.

Yamashita K., Sakai J., Hanada K. 1996. Characterization of a new virus from garlic (Allium sativum L.), garlic mite borne mosaic virus. Annals of the Phytopathological Society of Japan 62: 483-489.

Zavriev S.K., Kanyuka K.V., Levay K.E. 1991. The genome organization of Potato virus M RNA. Journal of General Virology 72: 9-14.

Zhou Z.Sh., Dell'Orco M., Saldarelli P., Turturo C., Minafra A., Martelli G.P. 2006. Identification of an RNA silencing suppressor in the genome of Grapevine virus A. Journal of General Virology 87: 2387-2395.

Zimmern D. 1987. Evolution of RNA viruses. p. 211-240. In: "RNA Genetics" (J. Holland, E.R. Domingo, P. Ahlquist, eds.). CRC Press, Boca Raton, FL, 365 pp. 